\title{
Domestic Violence in Kashmir: A Study from Sheikh Mohalla Srinagar
}

\author{
Dr. Pirzada M Amin \\ Associate Professor Department of Sociology \& Head of Department, Department of \\ Social Work, University of Kashmir, Hazratbal, Srinagar 190006 Jammu and Kashmir
}

\begin{abstract}
Domestic violence refers to violence against women especially in matrimonial homes. Domestic violence is one of the crimes against women which is linked to their disadvantageous position in the society. Therefore domestic violence is recognized as the significant barriers of the empowerment of women. The study will look into reasons and response to domestic violence in Srinagar. The researcher selected the area among various areas of district Srinagar on the basis of economic condition of areas. Interview schedule was used to collect the date from the respondents. Researcher approached the respondents using purposive sampling technique. The study results clearly showed that all the respondents were illiterate and most of them have no idea about domestic violence acts / laws. Most of the respondents were threatened by their partners or in -laws, both physical and verbal abuse takes place. The majority of victims did not even register their complaints with concern authorities. Domestic violence being a grave social problem, both government and non - governmental organizations should look into this issue and general public should be made aware how domestic violence is ethically and religiously wrong and how it damages social fiber.
\end{abstract}

Keywords: Abuse, dowry, domestic violence, in-laws, partner, women

\section{Introduction:}

Domestic violence is a pattern of abusive behavior in any relationship that is used by one partner to gain or maintain power and control over another intimate partner. Domestic violence can be physical, sexual, emotional, economic, or psychological actions or threats of actions that influence another person. This includes any behaviors that intimidate, manipulate, humiliate, isolate, frighten, terrorize, coerce, threaten, blame, hurt, injure, or wound someone (USDOJ) ${ }^{1}$. Any incident of threatening behaviour, violence or abuse (psychological, physical, sexual, financial or emotional) between adults who are or have been intimate partners or family members, regardless of gender or sexuality is domestic violence (DVL) ${ }^{2}$. The perpetrators of domestic violence have often been found to be the males and the victims, their sexual partners. Internationally, one in three women have been beaten, coerced into sex or abused in their lifetime by a member of her own family (Heise et al., 1999).

\section{Rationale:}

Domestic violence is a serious issue and is increasing day by day as the man progresses issues of domestic violence also come to limelight. Jammu and Kashmir is the second lowest state with 13 percent of domestic violence after Himachal Pradesh which has just 6 percent of domestic violence, lowest in India (NFHS, 2006). The study tried to look into domestic violence in Srinagar city in a low economic area, and tried to understand various aspects related to domestic violence, social, economic, administrative etc.

\section{Literature Review:}

A factor clearly responsible for inhibiting the choices of women in development is domestic violence. Abuse has been observed to impede the public participation of women, undermine their economic efficiency, cause increased health burdens, and impose a drain on scarce national resources (Heise et al., 1994). The study conducted in India indicates that physical abuse of Indian women is quite high, ranging from 22 percent to 60 percent of women surveyed it showed the lifestyle of men such as smoking, alcoholism and drugs promote men to commit domestic violence (Rao, 1996). Many other researchers also find same things to be responsible for the domestic violence, they indicated that influence of drugs, smoking, alcoholism, bad company, poverty promote men to commit domestic violence (Bhatt, 1998 and Mc Kenry et al., 1995). The number of family members, type of marriage and qualification of husband other to those menstrual problems has

\footnotetext{
${ }^{1} \mathrm{http}: / /$ www.ovw.usdoj.gov/domviolence.htm

${ }^{2}$ http://www.domesticviolencelondon.nhs.uk/1-what-is-domestic-violence-/1-definition.html
} 
significant influence on domestic violence (Murthy et. al., 2004). The low educational level and poverty are important reasons for domestic violence. Further, marriage at a younger age makes women vulnerable to domestic violence (Gerstein, 2000).

\section{Research Methodology:}

The researcher used quantitative approach. Whereas in quantitative approach non-probability sampling method was used, the purposive sampling technique was applied to ensure that the desired sample is selected.

\section{Data Collection and Sample Size}

The data was collected approximately in one month from 50 respondents. The interview schedule was used to collect the quantitative data.

\section{Universe Of Study}

The universe of study was selected district Srinagar in Kashmir, with in district Srinagar, areas where divided as per economic rating with seven point rating scale, Khathe -darwaza area in downtown of Srinagar district was selected based on rating with in Khathe - darwaza, Sheikh Colony was selected following the same procedure. Sheikh Colony or Mohallah has approximately 10 hundred to 15 hundred populations with around 100 houses. The main occupation of people in the area is being sweepers, and many others are vegetable sellers.

\section{Data Analysis}

The data collected with the help of interview schedules was first manually scrutinized to ensure that all the interview schedules are properly filled. The total of 50 interview schedules was analyzed. The frequency test was conducted to understand the ratio. Further the Chi-square tests were conducted to understand more facts.

Findings \& Interpretations:

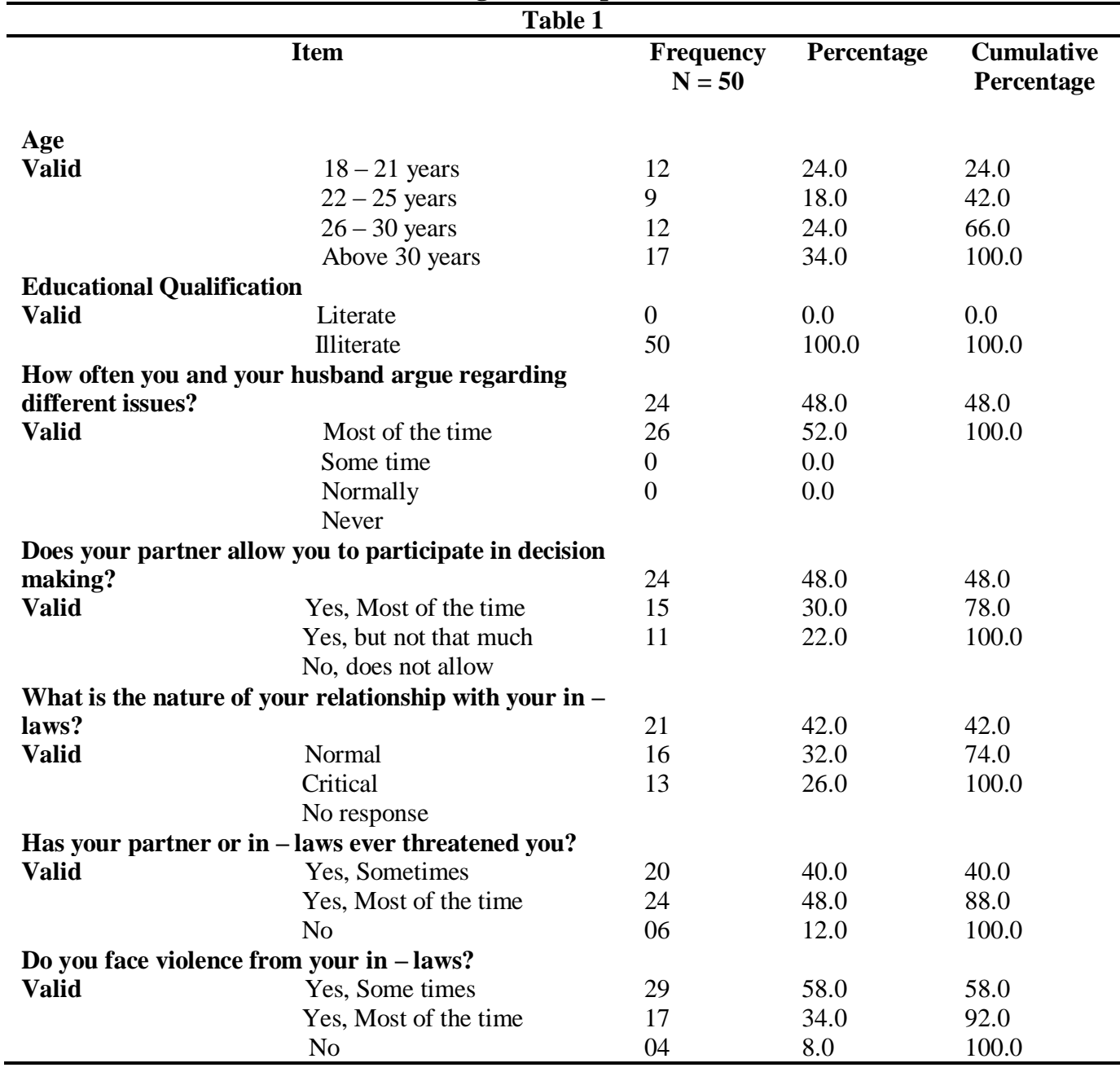


Domestic Violence in Kashmir: A study from Sheikh Mohalla Srinagar

\begin{tabular}{lllll}
\hline Have you ever resisted? & & & \\
Valid & Yes & 26 & 52.0 & 52.0 \\
& No & 13 & 26.0 & 78.0 \\
& No response & 11 & 22.0 & 100.0 \\
$\begin{array}{l}\text { How often you and your partner argue about sexual } \\
\text { relationship? }\end{array}$ & & & \\
Valid & Most of the time & 24 & 12.0 & 12.0 \\
& Some time & 48.0 & 60.0 \\
& Do not argue & 20 & 40.0 & 100.0 \\
$\begin{array}{l}\text { Have you reported domestic violence against you to } \\
\text { any authority? }\end{array}$ & & & \\
Valid & Yes to Police & 6 & 12.0 & \\
& Yes to Women's commission & 11 & 22.0 & 34.0 \\
& No & 33 & 66.0 & 100.0 \\
& Not applicable & 0 & 0.0 & \\
\hline
\end{tabular}

After analyzing table 1, it was revealed that 34 percent of respondents were in the age group of above 30 years, 24 percent were in the age group of $26-30$ years and $18-21$ years, however 18 percent of respondents belong to age group of $22-25$ years. Surprisingly 100 percent of respondents were illiterate. 52 percent of respondents mentioned that they and their partner argue on different issues sometimes, whereas 48 percent of respondents revealed that they their partner argue with them most of the time on different issues pertaining to life. 48 percent of respondents revealed that most of the time they are allowed by their partner to take part in decision making, 30 percent of respondents mentioned they are sometimes allowed to take part in decision making however, 22 percent of respondents revealed that they are not allowed to take part in decision making process in household. 42 percent of respondents revealed that their partner or in - laws has sometimes threaten them, 32 percent of respondents mentioned most of the times their partner or in - laws threaten them, whereas 26 percent of respondents revealed that the partner or in - laws do not threaten them. 48 percent of respondents mentioned they have critical relationship with their in - laws, 40 percent of respondents revealed they have normal relationship with their in - laws however, 12 percent of respondents did not responded to this question. 58 percent of respondents revealed that they sometimes face violence from their in - laws, 34 percent of respondents mentioned that they most of the times face violence from their in - laws; however 8 percent of respondent did not responded to this question. 52 percent of respondents revealed that they have resisted in against domestic violence, 26 percent of respondents mentioned they have not resisted in against domestic violence taking place against them. 48 percent of respondents mentioned that they and their partner sometimes argue over sexual relationship, 40 percent of respondents mentioned they do not argue however, 12 percent of respondents revealed that most of the times they argue with them partner over sexual relationship. 66 percent of respondents revealed they have never reported domestic violence against them to any authority, 22 percent of respondents mentioned they have reported to women's commission, whereas 12 percent of respondents mentioned they have reported to police.

To investigate further, Chi-square test was conducted to find the statistical significant difference between Age of respondents and How often they and their husband argue regarding different issues pertaining to family matters. $\left[\mathrm{X}^{2}(4)=16.194, \mathrm{P}<0.01\right.$, Cramer's $\left.\mathrm{V}=0.569\right]$. To find more statistical significance between variables, Chi-square test was conducted to find the statistical significant difference between Age of respondents and Have you ever reported domestic violence against you to any authority. $\left[\mathrm{X}^{2}(3)=26.173, \mathrm{P}<\right.$ 0.00 , Cramer's $\mathrm{V}=0.512]$. Furthermore, Chi-square test was conducted to find the statistical significant difference between Age of respondents and Role of Police regarding domestic violence. $\left[\mathrm{X}^{2}(3)=21.646, \mathrm{P}<\right.$ 0.01 , Cramer's V $=0.465]$.

\begin{tabular}{|c|c|c|c|c|}
\hline \multicolumn{5}{|c|}{ Table 2} \\
\hline & Item & $\begin{array}{c}\text { Frequency } \\
\mathbf{N}=\mathbf{5 0}\end{array}$ & Percentage & $\begin{array}{l}\text { Cumulative } \\
\text { Percentage }\end{array}$ \\
\hline \multicolumn{5}{|c|}{ Have you brought dowry at the time of marriage? } \\
\hline \multirow[t]{2}{*}{ Valid } & Yes & 8 & 16.0 & 16.0 \\
\hline & No & 42 & 84.0 & 100.0 \\
\hline \multicolumn{5}{|c|}{ Was there any demand from your in - laws or partner about } \\
\hline Valid & $\begin{array}{l}\text { Yes } \\
\text { No }\end{array}$ & 44 & 88.0 & 100.0 \\
\hline
\end{tabular}




\begin{tabular}{|c|c|c|c|c|}
\hline \multicolumn{5}{|c|}{ Did you face violence for giving fewer dowers? } \\
\hline \multirow[t]{3}{*}{ Valid } & Yes, verbal abuse & 36 & 72.0 & 72.0 \\
\hline & Yes, Physical abuse & 0 & 00.0 & 72.0 \\
\hline & No & 14 & 28.0 & 100.0 \\
\hline \multicolumn{5}{|c|}{ Are you aware of the domestic violence laws? } \\
\hline \multirow[t]{2}{*}{ Valid } & Yes & 14 & 28.0 & 28.0 \\
\hline & No & 36 & 72.0 & 100.0 \\
\hline \multicolumn{5}{|c|}{$\begin{array}{l}\text { Do you think police is playing its role efficiently in the } \\
\text { implementation of domestic violence laws? }\end{array}$} \\
\hline \multirow[t]{4}{*}{ Valid } & Yes, but not properly & 0 & 00.0 & 00.0 \\
\hline & Yes, Properly & 5 & 10.0 & 10.0 \\
\hline & Little bit, need to improve & 10 & 20.0 & 30.0 \\
\hline & No & 35 & 70.0 & 100.0 \\
\hline \multicolumn{5}{|c|}{$\begin{array}{l}\text { Do you feel a need for counselling centre or cell against } \\
\text { domestic violence? }\end{array}$} \\
\hline \multirow[t]{2}{*}{ Valid } & Yes, it will help in conflict resolution & 38 & 76.0 & 76.0 \\
\hline & No, it will have hardly any effect & 12 & 24.0 & 100.0 \\
\hline
\end{tabular}

After analyzing table 2, the things which were revealed as: 84 percent of respondents mentioned that they have not brought dowry along with them to husband's home at the time of their marriage, whereas 16 percent of respondents revealed they have brought dowry along with them to husband's home at the time of their marriage. 72 percent of respondents revealed that there was demand from their partners or in - laws side to bring dowry, however 28 percent mentioned there was no demand for dowry. 72 percent of respondents revealed they face violence most of the time for not bring dowry along with them, 28 percent however reveal they do not face any violence. 72 percent of respondents are not aware about laws against domestic violence, whereas 28 percent are aware about laws against domestic violence. 70 percent of respondents mentioned police do not play its role efficiently, 20 percent mentioned police play its role efficiently regarding matters pertaining to domestic violence, however 10 percent of respondents revealed police play little bit of the role in this regards. Interestingly responding to a question about need of counselling centre or cell, 76 percent of respondents revealed that counselling centre or cells are highly need to reduce conflicts within families and it can help reducing domestic violence, however 24 percent of respondents are of view it cannot bring any change in present situation regarding domestic violence.

To investigate further, Chi-square test was conducted to find the statistical significant difference between How often you \& your husband argue regarding different issues. And do you feel a need for counselling centre or cell against domestic violence. $\left[\mathrm{X}^{2}(2)=14.575, \mathrm{P}<0.00\right.$, Cramer's $\left.\mathrm{V}=0.540\right]$. Furthermore, Chi-square test was conducted to find the statistical significant difference between what is the nature of your relation with your in-laws and do you feel a need for counselling centre or cell against domestic violence. $\left[\mathrm{X}^{2}(2)=21.805, \mathrm{P}<0.00\right.$, Cramer's $\left.\mathrm{V}=0.660\right]$.

\section{Discussion:}

Gerstein (2000) argued that low educational level and poverty are important reasons for domestic violence. Murthy et al. (2004) argued that numbers of family members, type of marriage and in - laws attitude have significant influence on domestic violence. The same has been found by this study as 100 percent of respondents were illiterate and 72 percent of respondents do not have any idea about domestic violence act / laws. 88 percent of respondents mentioned that their partner or in - laws demanded dowry from them, which in terms enhanced domestic violence. Mishra (2000) \& Hindin (2002) argued that marriage at younger age makes women vulnerable to domestic violence the same has been justified by this study where age of respondents and domestic violence shows high significance to each other.

\section{Conclusion And Possible Solution:}

The foregoing analysis reveals that 48 percent of respondents where threatened by their partner or by in - laws, the data also reveals that 66 percent victims of domestic violence did not register their complaint with any authority like police or women's commission. At the same time 70 percent of respondents showed lack of trust on police and their work efficiency. 76 percent of respondents want counselling cell or center to be established so that family conflicts and other matters leading to domestic violence can be resolved. Looking at the analysed results it is visible that domestic violence has many root causes like early marriage, poverty, illiteracy, stress, depression, large family etc.

To reduce the domestic violence overall society need to take initiative against social evils like dowry, drug addiction, early marriage etc. Counselling at various spheres like in Masjids, Mohalla Committees meetings, at peer groups should take place regarding domestic violence. Government and Non - government agencies 
should take positive steps for reducing domestic violence, wherein government can strength their law enforcing agencies, Non - governmental agencies can setup counselling cells, organize community programs, form social groups for reducing violence through group work process.

\section{Acknowledgement:}

I am thankful to peer reviewers for reviewing this paper, I thank all the respondents who participated in this study despite facing so many problems in their lives, (I pray for their better and smooth life). At last but not least I would like to thank the editorial team and editor of this journal for accepting this article for publication on merit bases.

[1]. Bhatt, R. V. 1998. Domestic Violence and Substance Abuse. International Journal of Gynecology and Obstetrics. 63(Suppl.1) S25-31

[2]. Gerstein, L. 2000. In India, Poverty and Lack of Education are Associated with Men's Physical and Sexual abuse of their Wives. International Family Planning Perspectives, 26(1): 44-5.

[3]. Heise, L., Ellsberg, M and Gottemoeller, M. 1999. Ending Violence Against Women. Population Reports, Series L, No. 11 Baltimore, John Hopkins University School of Public Health, Population Information Program, December.

[4]. Heise, Lori, J. Pitanguy, and A. Germaine. 1994. "Violence against Women--The Hidden Health Burden." Washington DC: World Bank Discussion Papers.

[5]. Hindin, J.M. 2002. Who is at risk? Factors Associated with Intimate Partner Violence in the Philippines, Social Science and Medicine. 55:1385-1399.

[6]. McKenry, P.C; T. W. Julian and S. M. Gavazzi. 1995. Toward a Biopsychosocial Model of Domestic Violence. Journal of Marriage and the Family, 57: 307-20.

[7]. Murthy, M S R; P. Ganesh; J. Srivirajarani and R. Madhusudan. 2004. Proximate Determinants of Domestic Violence: An Exploratory Study on Role of Menstrual Problems and Life Style of Men'. Demography India. 33(1): 85-105.

[8]. Mishra, J. 2000. Women and Human Rights. Chapter V. Kalpaz Publications, New Delhi.

[9]. National Family Health Survey (2006), Government of India: http://www.rchiips.org/NFHS/nfhs3.shtml

[10]. Rao, V. 1996. "Wife-beating in rural south India: A qualitative and econometric analysis." Social Science and Medicine, 44(8): 1169-1180. 